\title{
SPK Penyeleksian Calon Presiden Mahasiswa Universitas Islam Riau Menggunakan Metode Fuzzy-AHP
}

\author{
Mundayani $^{1}$, Des Suryani ${ }^{2}$ \\ ${ }^{1,2}$ Program Studi Teknik Informatika, Fakultas Teknik, Universitas Islam Riau \\ e-mail: ${ }^{1}$ muntz.mundayani@gmail.com, ${ }^{2}$ des.suryani@eng.uir.ac.id
}

\begin{abstract}
Selection of student highway is a democratic party which was held among the students which is the beginning of a political education for students from an early age and became a selfactualizing and potential. One form is the student highway election presidential election students. Presidential election valid student at the Islamic University of Riau is still done manually so ineffective and inefficient. To solve these problems we need a decision support system that can provide the best decision for the users. Decision Support System (DSS) aims to determine the candidate elected president in the selection process is based on the importance of selection criteria and the data value of any established criteria. Decision support system and method using fuzzy analytic hierarchy process. Fuzzy method is used to determine the membership value of each value of the selection criteria, and methods of Analytic Hierarchy Process (AHP) is used to find the order of priority of the various alternatives in the process of solving a problem. The results of calculation of the decision support system in the form of ranking the candidates who have been elected student body president in the selection process. Beginning of the process of ranking the highest value that is owned by the presidential candidates and the number of students selected as presidential candidates based on the number of desired student in the period.
\end{abstract}

Keywords : AHP, DSS, fuzzy, Students presidential candidates.

\begin{abstract}
Abstrak
Pemilihan raya mahasiswa adalah sebuah pesta demokrasi yang diadakan di kalangan mahasiswa yang merupakan awal dari pendidikan politik sejak dini bagi mahasiswa dan menjadi tempat mengaktualisasikan diri dan potensi yang dimiliki. Salah satu bentuk pemilihan raya mahasiswa adalah pemilihan calon presiden mahasiswa. Pemilihan calon presiden mahasiswa yang berlaku di Universitas Islam Riau saat ini masih dilakukan secara manual sehingga tidak efektif dan tidak efisien. Untuk memecahkan permasalahan tersebut dibutuhkan suatu sistem pendukung keputusan yang dapat memberikan keputusan terbaik untuk penggunanya. Sistem Pendukung Keputusan (SPK) bertujuan untuk menentukan calon presiden yang terpilih dalam proses penyeleksian berdasarkan tingkat kepentingan kriteria dan data nilai seleksi dari setiap kriteria yang telah ditetapkan. Sistem pendukung keputusan menggunakan metode fuzzy dan metode analytic hierarchy process. Metode fuzzy digunakan untuk menentukan nilai keanggotaan dari tiap-tiap nilai seleksi berdasarkan kriteria, dan metode Analytic Hierarchy Process (AHP) digunakan untuk mencari urutan prioritas dari berbagai alternative dalam proses pemecahan suatu permasalahan. Hasil perhitungan sistem pendukung keputusan ini berupa perangkingan calon presiden mahasiswa yang telah terpilih dalam proses penyeleksian. Proses perangkingan dimulai dari nilai tertinggi yang dimiliki oleh calon presiden mahasiswa dan jumlah yang terpilih menjadi kandidat presiden mahasiswa berdasarkan jumlah yang diinginkan pada periode tersebut.
\end{abstract}

Kata kunci: AHP, Calon presiden mahasiswa, Fuzzy, SPK. 


\section{PENDAHULUAN}

Pemilihan Umum Raya (PEMIRA) adalah sebuah pesta demokrasi yang diadakan di kalangan mahasiswa Universitas Islam Riau. Kegiatan PEMIRA mahasiswa adalah untuk memilih presiden dan wakil presiden mahasiswa di Universitas Islam Riau. Momen ini merupakan awal dari pendidikan politik sejak dini bagi mahasiswa dan menjadi tempat mengaktualisasikan diri dan potensi yang dimiliki.

Pemilihan calon presiden mahasiswa dilakukan secara manual tidak efektif dan tidak efisien dikarenakan dengan jumlah 23.589 mahasiswa yang aktif dalam perkuliahan akan membutuhkan waktu yang rentan lama juga banyak terjadi salah penilaian sehingga keputusan yang diambil tidak sesuai dengan yang diharapkan. Untuk memecahkan permasalahan tersebut salah satunya dengan teknologi informasi yakni dengan cara membuatkan sistem pendukung keputusan untuk membantu memberikan keputusan yang terbaik bagi penggunanya, mempermudah dan mempercepat dalam penyelesaian masalah tersebut. Hal ini dikarenakan sistem pendukung keputusan adalah sistem informasi yang terkomputerisasi yang dirancang sebaik mungkin sehingga bersifat lebih interaktif dengan pengguna.

Tujuan dari penelitian ini adalah Untuk membuat sistem yang dapat membantu dewan mahasiswa dalam pemilihan presiden mahasiswa sebagai awal dalam pembentukan tatanan struktur organisasi himpunan mahasiswa di Universitas Islam Riau, dan untuk membuat sistem yang mampu memberikan solusi kepada BPRM untuk menentukan calon yang memenuhi syarat atau kriteria untuk menjadi calon presiden mahasiswa Universitas Islam Riau.

Beberapa penelitian telah dilakukan menggunakan metode fuzzy dan metode AHP untuk penyeleksian diantaranya: permasalahan yang dihadapi para siswa setelah lulus Sekolah Menengah Umum (SMU) (Alfi Dwi Sukmawan, 2008). Metode fuzzy dan metode AHP juga digunakan untuk proses pemilihan pemasok drum pelumas industri menggunakan fuzzy-AHP (D. A. Mardhikawarih, Wakhid Ahmad Jauhari, dan Cucuk Nur Rosyidi, 2012). Penelitian lain menggunakan metode fuzzy dan metode AHP untuk menyelesaikan permasalahan penerimaan beasiswa pada Universitas Pendidikan Indonesia (Muhammad Nur Prayogo, 2011), pengambilan keputusan untuk menentukan jumlah produksi barang dengan metode tsukamoto (Ginanjar Abdurrahman, 2011), struktur sebuah model AHP adalah model dari sebuah pohon terbaik dalam pemilihan lokasi perumahan (Armadyah Amborowati, 2012), dan sistem pendukung keputusan (SPK) pemilihan karyawan terbaik menggunakan metode fuzzy AHP (Jasril, Elin aerani, Iis Afrianty, 2011).

\section{METODE PENELITIAN}

\subsection{Pengumpulan Data}

Dalam proses pengumpulan data untuk mendapatkan data yang benar dan meyakinkan, peneliti melakukan teknik pengumpulan data sebagai berikut :

1. Teknik pengumpulan data primer, yaitu data yang diperoleh dengan melakukan penelitian secara langsung ke lokasi penelitian sesuai dengan masalah yang diteliti. Penelitian data ini dilakukan dengan cara:

a) Wawancara (interview) adalah metode pengumpulan data secara lisan dengan melakukan wawancara langsung kepada pihak-pihak yang berwenang di dalam organisasi tersebut.

b) Observasi (observation) adalah pengamatan langsung pada suatu objek yang akan diteliti untuk mendapatkan gambaran yanng tepat mengenai objek peneliti. 
2. Teknik pengumpulan data sekunder yaitu pengumpulan data dan informasi yang diperlukan/peroleh melalui catatan-catatan tertulis lainnya yang berkaitan dengan masalah yang diteliti. Penelitian data ini dilakukan dengan cara :

a) Penelitian kepustakaan (library research) adalah dengan mengumpulkan bukubuku, karya ilmiah, makalah yang memiliki relevansi dengan masalah yang diteliti.

\section{2 Konsep Teori}

Berisi tentang teori yang digunakan dalam penelitian. Bisa saja terdiri dari beberapa subbab seperti yang ditunjukkan section berikut ini.

\section{2.1 Sistem Pendukung Keputusan}

Sistem pendukung keputusan adalah sekumpulan prosedur berbasis model untuk data pemrosesan dan penilaian guna membantu para manajer mengambil keputusan. Menurut Turban (2005) dalam buku Kusrini (2007), mengatakan sistem pendukung keputusan merupakan suatu pendekatan untuk mendukung pengambilan keputusan. Sistem pendukung keputusan menggunakan data, memberikan antarmuka pengguna yang mudah, dan dapat menggabungkan pemikiran pengambil keputusan. Alter (2002) dalam buku Kusrini(2007), menyatakan bahwa sistem pendukung keputusan merupakan sistem informasi interaktif yang menyediakan informasi, pemodelan, dan pemanipulasian data.

\section{2.2 Logika Fuzzy}

Logika Fuzzy adalah suatu cara yang tepat untuk memetakan suatu ruang input ke dalam suatu ruang output. Dalam logika fuzzy untuk menyelesaikan suatu kondisi yang harus dilakukan adalah menentukan titik yang digambarkan dalam sebuah kurva yang akan digunakan (Prabowo Pudjo Widodo, 2012).

\section{2.3 Metode Analytic Hierarchy Process (AHP)}

Metode Analytic Hierarchy Process (AHP) dikembangkan oleh Prof. Thomas Lorie Saaty dari Wharton Business School di awal tahun 1970, yang digunakan untuk mencari rangking atau urutan prioritas dari berbagai alternatif dalam pemecahan suatu permasalahan. Dalam kehidupan sehari-hari, seseorang senantiasa dihadapkan untuk melakukan pilihan dari berbagai alternatif. Disini diperlukan penentuan prioritas dan uji konsistensi terhadap pilihan - pilihan yang telah dilakukan. Dalam situasi yang kompleks, pengambilan keputusan tidak dipengaruhi oleh satu faktor saja melainkan multifaktor dan mencakup berbagai jenjang maupun kepentingan. 


\section{3 Perancangan Sistem}

\subsubsection{Context Diagram}

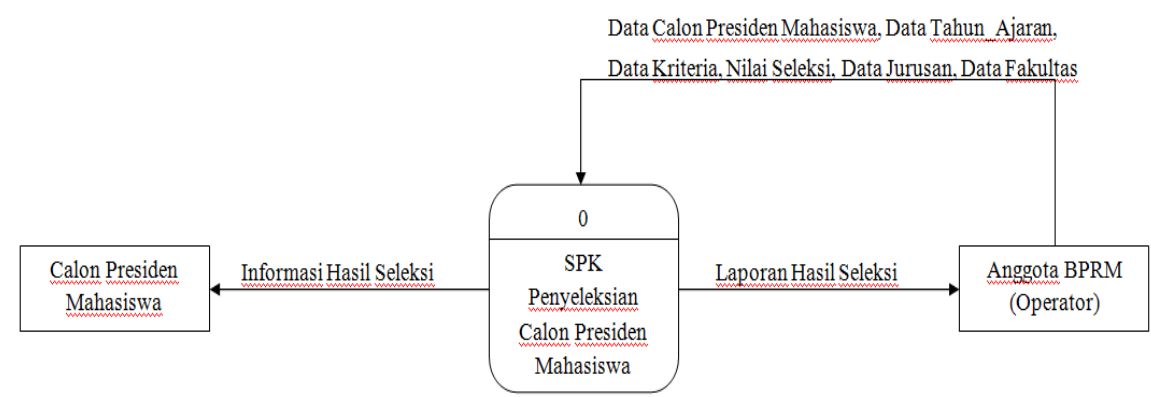

Gambar 1. Diagram Konteks Sistem Pendukung Keputusan Penyeleksian Calon Presiden Mahasiswa UIR

\subsubsection{Hierarchy Chart}

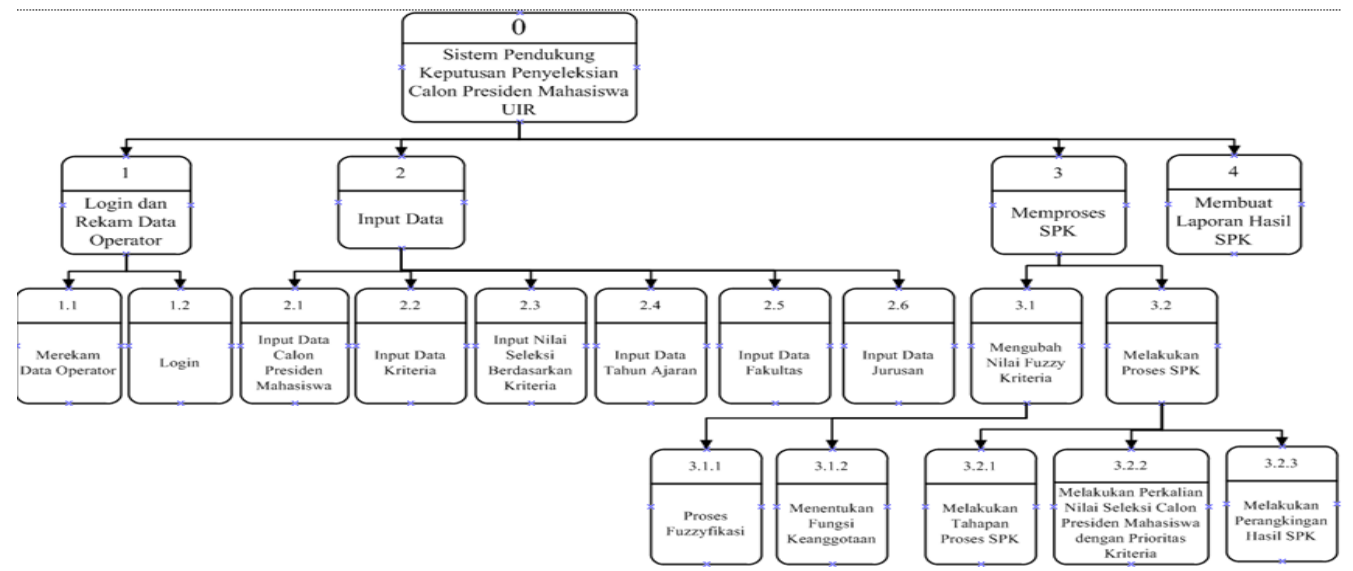

Gambar 2. Hierarchy Chart Sistem Pendukung Keputusan Penyeleksian Calon Presiden Mahasiswa UIR

\subsubsection{Data Flow Diagram (DFD)}

Berikut adalah DFD level 0 yang merupakan representasi grafis dari aliran data yang ada didalam sistem penyeleksian calon presiden mahasiswa UIR. Proses DFD level 0 terlihat pada Gambar 3. 


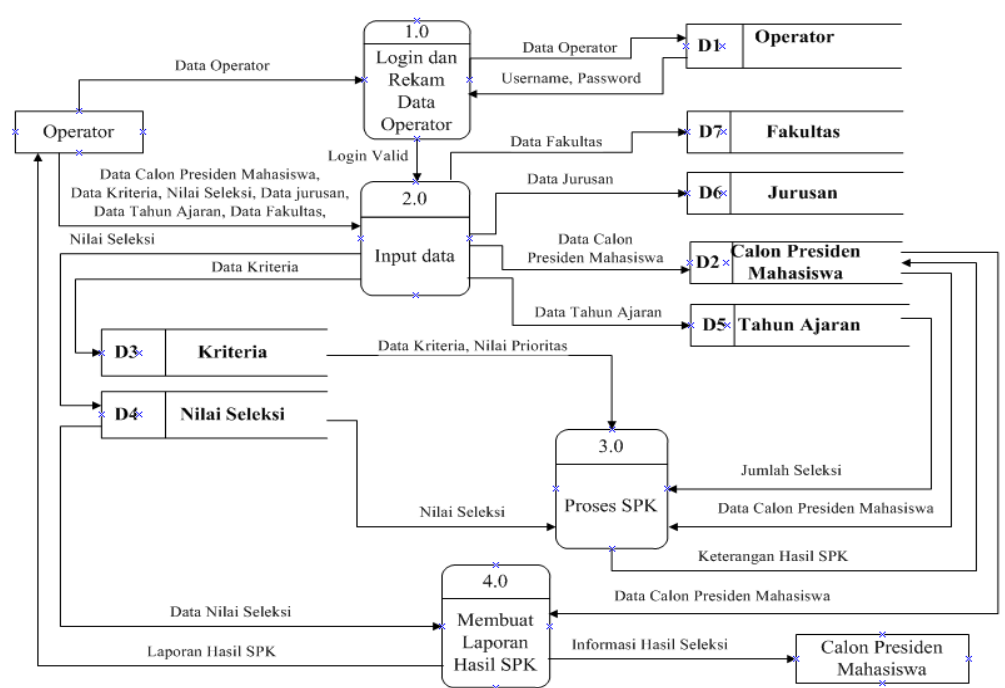

Gambar 3. Data Flow Diagram Level 0

\subsubsection{Entity Relationship Diagram}

Entity Relationship Diagram (ERD) adalah gambaran mengenai berelasinya antar entitas. Adapun gambaran relasi yang terjadi antara entitas-entitas utama tersebut tergambar dalam diagram Gambar 4.

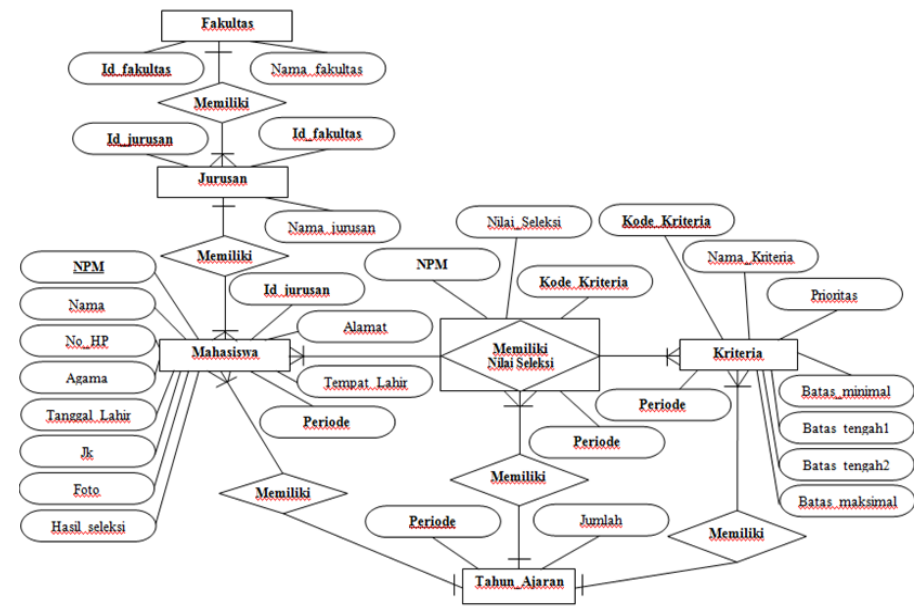

Gambar 4. Entity Relationship Diagram

\section{HASIL DAN PEMBAHASAN}

Data yang digunakan dalam penelitian ini adalah data sampel sebagai berikut :

Tabel 1. Data Sampel Nilai Seleksi Calon Presiden Mahasiswa

\begin{tabular}{|l|c|c|c|c|c|}
\hline \multicolumn{1}{|c|}{ KriterialMahasiswa } & $\begin{array}{c}\text { Ahma } \\
\text { Faiz }\end{array}$ & $\begin{array}{c}\text { Fauzan } \\
\text { Ramadhan }\end{array}$ & $\begin{array}{c}\text { Doni } \\
\text { Saputra }\end{array}$ & M.Ilham & $\begin{array}{c}\text { Eko } \\
\text { Prasetyo }\end{array}$ \\
\hline Pengalaman Organisasi & 6 & 4 & 3 & 5 & 7 \\
\hline Nilai IPK & 3,00 & 3,75 & 3,05 & 2,75 & 2,85 \\
\hline
\end{tabular}


Vol.1, No.1, Juli 2016

\begin{tabular}{|l|c|c|c|c|c|}
\hline Dukungan Fakultas & 210 & 300 & 230 & 250 & 400 \\
\hline Dukungan Organisasi & 7 & 5 & 6 & 10 & 6 \\
\hline Semester & 13 & 11 & 9 & 7 & 7 \\
\hline $\begin{array}{l}\text { Hasil TPA (Jumlah Soal } \\
\text { yang benar) }\end{array}$ & 18 & 10 & 12 & 15 & 17 \\
\hline $\begin{array}{l}\text { Hasil Tes Membaca } \\
\text { Al-Qur'an }\end{array}$ & 90 & 80 & 65 & 75 & 85 \\
\hline
\end{tabular}

Dalam penelitian ini ada dua tahapan yang dilakukan yakni proses fuzzy dan proses AHP. Proses fuzzy yang terjadi adalah menentukan nilai keanggotaan dari setiap nilai seleksi yang telah di-input-kan. Setiap nilai seleksi dihitung nilai keanggotaannya berdasarkan kurva yang telah ditentukan. Pada kriteria pengalaman organisasi yang memiliki batasan 2-10, menggunakan kurva linear naik dengan rumus :

$$
\mu[x]=\left\{\begin{array}{cc}
0 ; & x \leq a \\
\frac{(x-a)}{(b-a)} & a \leq x \leq b \\
1 ; & x \geq b
\end{array}\right.
$$

Sehingga nilai keanggotaan untuk ;

Sampel 1 (Ahmad Faiz) : (x-a) / (b-a) $=(6-2) /(10-2)=4 / 8=0,5$

Sampel 2 (Fauzan Ramadhan) : (x-a) / (b-a) $=(4-2) /(10-2)=2 / 8=0,25$

Sampel 3 (Doni Saputra) : (x-a) $/(\mathrm{b}-\mathrm{a})=(3-2) /(10-2)=1 / 8=0,125$

Sampel 4 (Muhammad Ilham) : (x-a) / (b-a) $=(5-2) /(10-2)=3 / 8=0,375$

Sampel 5 (Eko Prasetyo) : (x-a) / (b-a) $=(7-2) /(10-2)=5 / 8=0,625$

Sampel 6 (Maria) : Tidak diproses karena sudah terseleksi pada kriteria agama.

Pada kriteria nilai IPK yang memiliki batasan 2,75-4, menggunakan kurva linear naik dengan rumus :

$$
\mu[x]=\left\{\begin{array}{cc}
0 ; & x \leq a \\
\frac{(x-a)}{(b-a)} & a \leq x \leq b \\
1 ; & x \geq b
\end{array}\right.
$$

Sehingga nilai keanggotaan untuk ;

Sampel 1 (Ahmad Faiz) : (x-a) / (b-a) $=(3,00-2,75) /(4-2,75)=0,25 / 1,25=0,2$

Sampel 2 (Fauzan Ramadhan) : $(\mathrm{x}-\mathrm{a}) /(\mathrm{b}-\mathrm{a})=(3,75-2,75) /(4-2,75)=1 / 1,25=0,2$

Sampel 3 (Doni Saputra) : $(x-a) /(b-a)=(3,05-2,75) /(4-2,75)=0,3 / 1,25=0,24$

Sampel 4 (Muhammad Ilham) : (x-a) / (b-a) $=(2,75-2,75) /(4-2,75)=0 / 1,25=0$

Sampel 5 (Eko Prasetyo) : (x-a) / (b-a) $=(2,85-2,75) /(4-2,75)=0,1 / 1,25=0,08$

Pada kriteria dukungan fakultas yang memiliki batasan 200-600, menggunakan kurva linear naik dengan rumus :

$$
\mu[x]=\left\{\begin{array}{cc}
0 ; & x \leq a \\
\frac{(x-a)}{(b-a)} & a \leq x \leq b \\
1 ; & x \geq b
\end{array}\right.
$$

Sehingga nilai keanggotaan untuk ;

Sampel 1 (Ahmad Faiz) : (x-a) / (b-a) $=(210-200) /(600-200)=10 / 400=0,025$

Sampel 2 (Fauzan Ramadhan) : $(x-a) /(b-a)=(300-200) /(600-200)=100 / 400=0,25$

Sampel 3 (Doni Saputra) : (x-a) / (b-a) $=(230-200) /(600-200)=30 / 400=0,075$

Sampel 4 (Muhammad Ilham) : $(\mathrm{x}-\mathrm{a}) /(\mathrm{b}-\mathrm{a})=(250-200) /(600-200)=50 / 400=0,125$

Sampel 5 (Eko Prasetyo) : (x-a) $/(\mathrm{b}-\mathrm{a})=(400-200) /(600-200)=200 / 400=0,5$ 
Pada kriteria dukungan organisasi yang memiliki batasan 5-20, menggunakan kurva linear naik dengan rumus :

$$
\mu[x]=\left\{\begin{array}{cc}
0 ; & x \leq a \\
\frac{(x-a)}{(b-a)} & a \leq x \leq b \\
1 ; & x \geq b
\end{array}\right.
$$

Sehingga nilai keanggotaan untuk ;

Sampel $1($ Ahmad Faiz) $:(x-a) /(b-a)=(7-5) /(20-5)=2 / 15=0,025$

Sampel 2 (Fauzan Ramadhan) : (x-a) / (b-a) $=(5-5) /(20-5)=0 / 15=0$

Sampel 3 (Doni Saputra) : $(x-a) /(b-a)=(6-5) /(20-5)=1 / 15=0,067$

Sampel 4 (Muhammad Ilham) : (x-a) / (b-a) $=(10-5) /(20-5)=5 / 15=0,333$

Sampel 5 (Eko Prasetyo) : (x-a) $/(b-a)=(6-5) /(20-5)=1 / 15=0,067$

Pada kriteria semester yang memiliki batasan 5-7-9-11, menggunakan kurva trapesium dengan rumus :

$$
\mu[x]=\left\{\begin{array}{c}
0 ; x \leq a \text { atau } x \geq d \\
\frac{(x-a)}{(b-a)} ; a \leq x \leq b \\
(1) ; b \leq x \leq c \\
\frac{(d-x)}{(d-c)} ; c \leq x \leq d
\end{array}\right.
$$

Sehingga nilai keanggotaan untuk ;

Sampel 1 (Ahmad Faiz) : 0

Sampel 2 (Fauzan Ramadhan) : (d-x) / (d-c) $=(11-11) /(11-9)=0 / 2=0$

Sampel 3 (Doni Saputra) : (d-x) $/(\mathrm{d}-\mathrm{c})=(11-9) /(11-9)=2 / 2=1$

Sampel 4 (Muhammad Ilham) : (x-a) / (b-a) $=(7-5) /(7-5)=2 / 2=1$

Sampel 5 (Eko Prasetyo) : (x-a) / (b-a) $=(7-5) /(7-5)=2 / 2=1$

Pada kriteria hasil TPA yang memiliki batasan 1-20, menggunakan kurva linear naik dengan rumus :

$$
\mu[x]=\left\{\begin{array}{cc}
0 ; & x \leq a \\
\frac{(x-a)}{(b-a)} & a \leq x \leq b \\
1 ; & x \geq b
\end{array}\right.
$$

Sehingga nilai keanggotaan untuk ;

Sampel 1 (Ahmad Faiz) : (x-a) / (b-a) $=(18-1) /(20-1)=17 / 19=0,895$

Sampel 2 (Fauzan Ramadhan) : (x-a) / (b-a) $=(10-1) /(20-1)=9 / 19=0,474$

Sampel 3 (Doni Saputra) : (x-a) $/(b-a)=(12-1) /(20-1)=11 / 19=0,579$

Sampel 4 (Muhammad Ilham) : (x-a) / (b-a) $=(15-1) /(20-1)=14 / 19=0,737$

Sampel 5 (Eko Prasetyo) : (x-a) $/(b-a)=(17-1) /(20-1)=16 / 19=0,842$

Pada kriteria hasil membaca Al-Qur'an yang memiliki batasan 60-90, menggunakan kurva linear naik dengan rumus :

$$
\mu[x]=\left\{\begin{array}{cc}
0 ; & x \leq a \\
\frac{(x-a)}{(b-a)} & a \leq x \leq b \\
1 ; & x \geq b
\end{array}\right.
$$

Sehingga nilai keanggotaan untuk ;

Sampel 1 (Ahmad Faiz) : (x-a) / (b-a) $=(90-60) /(90-60)=30 / 30=1$

Sampel 2 (Fauzan Ramadhan) : (x-a) / (b-a) $=(80-60) /(90-60)=20 / 30=0,667$

Sampel 3 (Doni Saputra) : (x-a) / (b-a) $=(65-60) /(90-60)=5 / 30=0,167$

Sampel 4 (Muhammad Ilham) : (x-a)/ (b-a) $=(75-60) /(90-60)=15 / 30=0,5$ 
Sampel 5 (Eko Prasetyo) : (x-a) / (b-a) $=(85-60) /(90-60)=25 / 30=0,833$

Hasil proses fuzzy terlihat seperti pada gambar berikut ini :

\begin{tabular}{|c|c|c|c|c|c|c|}
\hline \multicolumn{7}{|l|}{ 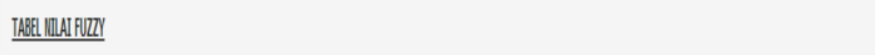 } \\
\hline Kriterial/Kahasiswa & 08651045 & 09651022 & 10551032. & 113510101 & 1135510375 & 123110088 \\
\hline PECGGLLWAN ORGANSSES & 0 & 0.5 & 0.125 & 0375 & 0665 & 0 \\
\hline NILA IPR & 0 & 0.2 & 024 & 0 & 008 & 0 \\
\hline DUKUNCAN FAKUTIAS & 0 & 0.065 & 0075 & 0.125 & 0.5 & 0 \\
\hline DUKUNGAN ORGANISSSI & 0 & 0.5 & 05 & 0.15 & 0.5 & 0.15 \\
\hline SEHESTER & 0 & & 0 & 1 & 1 & 1 \\
\hline HASLL TES TPA & 0 & 0895 & 0.59 & 0.737 & 0842 & 0137 \\
\hline HASLL TES AL-OURAAK & 0 & 1 & 0.167 & 0.5 & 0833 & 0833 \\
\hline
\end{tabular}

Gambar 5. Tampilan Proses Fuzzy

Setelah proses fuzzy selesai, proses selanjutnya adalah proses SPK dengan metode AHP. Tahapan yang dilakukan pada proses AHP adalah menentukan prioritas kepentingan untuk setiap kriteria yang telah di-input-kan, maka tampilannya akan terlihat seperti pada Gambar 6.

\begin{tabular}{|c|c|c|}
\hline \multicolumn{3}{|c|}{ TABEL PRIORITAS } \\
\hline Kode Kriteria & Nama Kriteria & Prioritas \\
\hline 0001 & \begin{tabular}{|l|} 
PENGALAMAN ORCANISASI \\
\end{tabular} & 7 \\
\hline 0002 & NILAI IPK & 2 \\
\hline 0003 & DUKUNGAN FAKULTAS & 4 \\
\hline 0004 & DUKUNGAN ORGANISASI & 6 \\
\hline 0005 & SEMESTER & 1 \\
\hline 0006 & HASIL TES TPA & 3 \\
\hline 0007 & HASIL TES AL-QUR'AN & 5 \\
\hline
\end{tabular}

Gambar 6. Tampilan Tabel Prioritas

Kemudian proses selanjutnya adalah menentukan matriks berpasangan dan matriks nilai kriteria seperti pada Gambar 7.

\begin{tabular}{|c|c|c|c|c|c|c|c|c|c|c|}
\hline Kriteria & \multirow{2}{*}{\multicolumn{2}{|c|}{$\begin{array}{l}\text { Ooo1 } \\
7 / 7=1\end{array}$}} & \multicolumn{2}{|l|}{0002} & 0003 & \multicolumn{2}{|l|}{0004} & 0005 & \multirow{2}{*}{$\begin{array}{l}\text { 0006 } \\
7 / 3=2.333\end{array}$} & \multirow{2}{*}{$\begin{array}{l}\text { o0o7 } \\
7 / 5=1.4\end{array}$} \\
\hline 0001 & & & $7 / 2=3$ & & $7 / 4=1.75$ & \multirow{2}{*}{\multicolumn{2}{|c|}{$2 / 6=0.333$}} & \multirow{2}{*}{$2 / 1=2$} & & \\
\hline 0002 & \multicolumn{2}{|l|}{$2 / 7=0.286$} & \multicolumn{2}{|c|}{$2 / 2=1$} & $2 / 4=0.5$ & & & & $2 / 3=0.667$ & $2 / 5=0.4$ \\
\hline 0003 & \multirow{2}{*}{\multicolumn{2}{|c|}{$\begin{array}{l}4 / 7=0.571 \\
6 / 7=0.857\end{array}$}} & \multirow{2}{*}{\multicolumn{2}{|c|}{$\begin{array}{l}4 / 2=2 \\
6 / 2=3\end{array}$}} & $4 / 4=1$ & \multicolumn{2}{|l|}{$4 / 6=0.667$} & $4 / 1=4$ & $4 / 3=1.333$ & $4 / 5=0.8$ \\
\hline 0004 & & & & & \multirow{2}{*}{$\begin{array}{l}6 / 4=1.5 \\
1 / 4=0.25\end{array}$} & \multirow{2}{*}{\multicolumn{2}{|c|}{$\begin{array}{l}6 / 6=1 \\
1 / 6=0.167\end{array}$}} & $6 / 1=6$ & \multirow{2}{*}{$\begin{array}{l}6 / 3=2 \\
1 / 3=0.333\end{array}$} & $6 / 5=1.2$ \\
\hline ooos & \multicolumn{2}{|l|}{$1 / 7=0.143$} & \multicolumn{2}{|c|}{$1 / 2=0.5$} & & & & \multirow{2}{*}{$3 / 1=3$} & & $1 / 5=0.2$ \\
\hline 0006 & \multirow{2}{*}{\multicolumn{2}{|c|}{$\begin{array}{l}3 / 7=0.429 \\
5 / 7=0.714\end{array}$}} & \multirow{2}{*}{\multicolumn{2}{|c|}{$\begin{array}{l}3 / 2=1.5 \\
5 / 2=2.5\end{array}$}} & \multirow{2}{*}{$\begin{array}{l}3 / 4=0.75 \\
5 / 4=1.25\end{array}$} & \multicolumn{2}{|l|}{$\begin{array}{l}3 / 6=0.5 \\
5 / 6=0.833\end{array}$} & & \multirow{2}{*}{$\begin{array}{l}3 / 3=1 \\
5 / 3=1.667\end{array}$} & $3 / 5=0.6$ \\
\hline 0007 & & & & & & $5 / 6=0.833$ & & $5 / 1=5$ & & $5 / 5=1$ \\
\hline Jumlah & \multicolumn{2}{|l|}{4} & \multicolumn{2}{|c|}{14} & 7 & \multicolumn{2}{|l|}{4.667} & 28 & 9.333 & 5.6 \\
\hline ABEL MA & RITERIA & & & & & & & & & \\
\hline Kriteria & 0001 & 0002 & & 0003 & 0004 & 0005 & 0006 & 0007 & Jumlah & Prioritas \\
\hline 0001 & 0.25 & 0.25 & & 0.25 & 0.25 & 0.25 & 0.25 & 0.25 & 1.75 & 0.25 \\
\hline 0002 & 0.072 & 0.071 & & 0.071 & 0.071 & 0.071 & 0.071 & 0.071 & 0.498 & 0.071 \\
\hline 0003 & 0.143 & 0.143 & & 0.143 & 0.143 & 0.143 & 0.143 & 0.143 & 1.001 & 0.143 \\
\hline 0004 & 0.214 & 0.214 & & 0.214 & 0.214 & 0.214 & 0.214 & 0.214 & 1.498 & 0.214 \\
\hline 0005 & 0.036 & 0.036 & & 0.036 & 0.036 & 0.036 & 0.036 & 0.036 & 0.252 & 0.036 \\
\hline 0006 & 0.107 & 0.107 & & 0.107 & 0.107 & 0.107 & 0.107 & 0.107 & 0.749 & 0.107 \\
\hline 0007 & 0.179 & 0.179 & & 0.179 & 0.178 & 0.179 & 0.179 & 0.179 & 1.252 & 0.179 \\
\hline
\end{tabular}

Gambar 7. Tampilan Tabel Matriks Berpasangan dan Tabel Matriks Kriteria

Pada tabel matriks berpasangan tiap kriteria dibandingkan dengan kriteria lainnya. Kemudian jumlahkan tiap kolom dan hasil penjumlahan tersebut digunakan untuk menghitung nilai prioritas dari setiap kriteria seperti yang terlihat pada tabel matriks kriteria pada gambar 7. Tahapan selanjutnya menentukan matrik hasil akhir. Matriks hasil akhir didapat dari perkalian matriks fuzzy dan matriks nilai kriteria. Matriks hasil akhir merupakan array dua dimensi, yakni kriteria dan calon presiden mahasiswa UIR. Tahapan selanjutnya adalah menentukan rangking hasil seleksi dari tiap data calon presiden 
mahasiswa. Pada tahapan ini perangkingan diurutkan dari hasil seleksi tertinggi sampai terendah. Jumlah data pada perangkingan yang ditampilkan sesuai dengan jumlah kandidat atau calon yang dibutuhkan pada tahun ajaran proses penyeleksian dilakukan. Hasil dalam menentukan perangkingan terlihat seperti pada Gambar 8.

\begin{tabular}{|c|c|c|c|c|c|c|}
\hline \multicolumn{2}{|c|}{ Kriteria/Mahasiswa } & 086510222 & 096510425 & 103510322 & 113510101 & 113510375 \\
\hline \multicolumn{2}{|l|}{0001} & 0.688 & 0.612 & 0.564 & 0.767 & 0.987 \\
\hline \multicolumn{2}{|l|}{0002} & 0.196 & 0.174 & 0.16 & 0.219 & 0.282 \\
\hline & 0.395 & 0.349 & 0.323 & 0.44 & 0.564 \\
\hline & 0.589 & 0.523 & 0.482 & 0.657 & 0.844 \\
\hline \multicolumn{2}{|l|}{0005} & 0.099 & 0.088 & 0.082 & 0.112 & 0.142 \\
\hline \multirow{2}{*}{\multicolumn{2}{|c|}{$\begin{array}{l}0006 \\
0007\end{array}$}} & 0.295 & 0.262 & 0.241 & 0.329 & 0.423 \\
\hline & & 0.493 & 0.437 & 0.403 & 0.549 & 0.707 \\
\hline \multicolumn{2}{|l|}{ Jumlah } & \multirow{2}{*}{$\begin{array}{l}2.755 \\
3\end{array}$} & 2.445 & 2.255 & 3.073 & 3.949 \\
\hline \multicolumn{2}{|l|}{ Rangking } & & 4 & 5 & 2 & 1 \\
\hline \multicolumn{7}{|c|}{ DAFTAR CALON PRESIDEN MAHASISWA UIR } \\
\hline No & \multicolumn{2}{|l|}{ NPM } & \multicolumn{2}{|c|}{ NAMA MAHASISWA } & \multicolumn{2}{|c|}{ KETERANGAN } \\
\hline 1 & \multicolumn{2}{|l|}{113510375} & \multicolumn{2}{|c|}{ EKO PRASETYO } & \multicolumn{2}{|l|}{3.949} \\
\hline 2 & \multicolumn{2}{|l|}{113510101} & \multicolumn{2}{|c|}{ MUHAMMAD ILHAM } & \multicolumn{2}{|l|}{3.073} \\
\hline 3 & \multicolumn{2}{|l|}{086510222} & \multicolumn{2}{|c|}{ AHMAD FAIZ } & \multicolumn{2}{|l|}{2.755} \\
\hline
\end{tabular}

Gambar 8. Tampilan Hasil Perangkingan

\section{KESIMPULAN}

Berdasarkan pemaparan mengenai hasil analisis sistem pendukung keputusan penyeleksian calon presiden mahasiswa universitas islam riau menggunakan metode fuzzy dan metode Analytic Hierarchy Process (AHP), akan dapat disimpulkan sebagai berikut :

a. Dengan adanya sistem pendukung keputusan ini akan memudahkan anggota BPRM untuk melakukan penyeleksian terhadap mahasiswa yang mencalonkan diri untuk menjadi calon presiden mahasiswa karena proses penyeleksian dilakukan oleh system. Anggota BPRM hanya menginputkan data-data yang diperlukan dalam proses penyeleksian, sedangkan proses perhitungannya dilakukan sepenuhnya oleh sistem.

b. Sistem ini dapat menghemat waktu penyeleksian. Hal ini terlihat dalam agenda pemilihan raya mahasiswa secara manual membutuhkan waktu 5 (lima) hari, sedangkan dengan menggunakan sistem, proses seleksi dilakukan dalam 1 (satu) hari. Selain itu sistem ini juga dapat meng-efisiensi-kan penyimpanan data, maka keamanan data akan lebih terjamin, serta mengurangi penilaian yang bersifat subjektif karna proses seleksi data dilakukan oleh sistem.

c. Sistem ini hanya memproses kriteria yang memiliki nilai dan mengesampingkan ketepatan penyerahan berkas dan keabsahan berkas dari calon presiden mahasiswa.

d. Berdasarkan hasil persentase kuisioner yang telah dilakukan, sistem ini dapat membantu kinerja anggota BPRM dari segi waktu dan dari segi proses penyeleksian calon presiden mahasiswa berdasarkan kriteria yang telah ditetapkan.

\section{SARAN}

Saran untuk mengembangkan sistem pendukung keputusan penyeleksian calon presiden mahasiswa universitas islam riau menggunakan metode fuzzy dan metode Analytic Hierarchy Process (AHP) adalah sebagai berikut :

a) Pada sistem ini kriteria yang digunakan hanya kriteria yang memiliki nilai dan diharapkan untuk kedepannya dapat dikembangkan lebih banyak lagi kriteria yang digunakan dengan memperhitungkan ketepatan waktu dan keabsahan dari berkas calon presiden mahasiswa untuk mendapatkan hasil yang lebih baik. 
b) Pada sistem ini metode fuzzy yang digunakan hanya sampai pada menghitung nilai keanggotaan. Sehingga diharapkan pada penelitian selanjutnya dapat menggunakan metode fuzzy lain untuk bahan penelitian seperti metode fuzzy mamdani dan lain -lain.

\section{DAFTAR PUSTAKA}

[1] Abdurrahman, Ginanjar., 2011, Penerapan Metode Tsukamoto (Logika Fuzzy) dalam Sistem Pendukung Keputusan untuk Menentukan Jumlah Produksi Barang Berdasarkan Data Persediaan dan Jumlah Permintaan, Skripsi, Program Studi Matematika, Universitas Negeri Yogyakarta, Yogyakarta.

[2] Amborowati, Armadyah., Sistem Penunjang Keputusan Pemilihan Perumahan dengan Metode AHP Menggunakan Expert Choice, Jurnal, STMIK AMIKOM Yogyakarta, Yogyakarta.

[3] Ardhana, YM Kusuma., 2012, PHP Menyelesaikan Website 30 Juta, Jasakom, Purwokerto.

[4] Jasril, dkk., 2011, Sistem Pendukung Keputusan (SPK) Pemilihan Karyawan Terbaik Menggunakan Metode Fuzzy AHP (F-AHP), Jurnal, Jurusan Teknik Informatika, Universitas Islam Sultan Syarif Kasim Riau, Pekanbaru.

[5] Kadir, Abdul., 2009, Mastering Ajax dan PHP, Andi Offset, Yogyakarta.

[6]___., 2013, Pemrograman Database MySQL Untuk Pemula, MediaKom, Yogyakarta.

[7] Kusumadewi, Sri.,dkk., 2006, Fuzzy Multi-Attribute Decision Making (Fuzzy MADM), Graha Ilmu, Yogyakarta.

[8] Kusumadewi, Sri., Purnomo, Hari., 2010, Aplikasi Logika Fuzzy Untuk Pendukung Keputusan, Graha Ilmu, Yogyakarta.

[9] Kusrini., 2007, Konsep dan Aplikasi Sistem Pendukung Keputusan, Andi Offset, Yogyakarta.

[10]Mahya, Isna Ainul., 2008, Sistem Pendukung Keputusan untuk Menentukan Kualitas Produksi Ayam Petelur, Skripsi, Jurusan Teknik Informatika, Universitas Islam Negeri (UIN) Malang, Malang.

[11]Mardhikawarih,D.A.,dkk., 2012, Pemilihan Pemasok Drum Pelumas Industri Menggunakan Fuzzy Analytical Hierarchy Process, Jurnal, Vol 11, No 1 : 67-74.

[12]Prayogo, Muhammad Nur., Sistem Pendukung Keputusan Untuk Menentukan Penerima Beasiswa Menggunakan Algoritma Genetika Dengan Metode Fuzzy Logic Sebagai Inisialisasi Awal (Studi Kasus: Mahasiswa Fakultas Pendidikan Matematika Dan Ilmu Pengetahuan Alam Universitas Pendidikan Indonesia), Jurnal, Jurusan Ilmu Komputer, Universitas Pendidikan Indonesia, Bandung.

[13]Sinaga, Johannes., 2009, Penerapan Analytical Hierarchy Process (AHP) dalam Pemilihan Perusahaan Badan Usaha Milik Negara (BUMN) Sebagai Tempat Kerja Mahasiswa Universitas Sumatera Utara (USU), Skripsi, Departemen Matematika, Universitas Sumatera Utara, Medan.

[14]Sukmawan, Alfi Dwi., 2008, Sistem Pendukung Keputusan Pemilihan Jurusan di Perguruan Tinggi, Skripsi, Jurusan Teknik Informatika, Universitas Islam Negeri Malang, Malang.

[15]Syaifullah., 2010, Pengenalan Analytical Hierarchy Process, Syaifullah08. Wordpress.Com, http://syaifullah08.files.wordpress.com/pengenalan-analytical-hierarchyprocess.pdf (di akses 29 Oktober 2012).

[16]Widodo, Prabowo Pudjo., Handayanto, Rahmadya Trias., 2012, Penerapan Soft Computing Dengan Matlab, Rekayasa Sains, Bandung. 
[17]Winiarti, Sri., Yuraida, Ulfah., 2009, Aplikasi Sistem Pendukung Keputusan Penentuan Lokasi Pendirian Warnet Dengan Metode Analytical Hierarchy Process (AHP), Jurnal Informatika, Vol $3: 2$. 